\title{
Disseminating the knowledge on the complex interactions between humans and volcanoes: the geological section of the Villa Arbusto archaeological museum at Lacco Ameno (Ischia, Naples - Italy)
}

\author{
Sandro de Vita*,1, Mauro A. Di Vito ${ }^{1}$, Diana Barra ${ }^{1,2}$, Giuseppe Aiello ${ }^{2}$, \\ Costanza Gialanella ${ }^{3}$ \\ ${ }^{(1) 1}$ Istituto Nazionale di Geofisica e Vulcanologia, Osservatorio Vesuviano, Sezione di Napoli \\ ${ }^{(2)}$ Dipartimento di Scienze della Terra, dell'Ambiente e delle Risorse (DiSTAR), Università degli Studi di Napoli Federico II \\ (3)Soprintendenza Archeologia Belle Arti e Paesaggio per il comune di Napoli, Napoli
}

Article history: received April 1, 2021; accepted October 22, 2021

\begin{abstract}
A room in the Archaeological Museum of Villa Arbusto (Lacco Ameno, Ischia) was set up to house rocks and fossils collected by the renowned archaeologist Giorgio Buchner during his excavation activity on the Island of Ischia. The collection is witness to a long multidisciplinary research activity that saw archaeological studies at the center of volcanological, pedological and palaeoenvironmental researches, aimed at reconstructing the archaeological contexts in the complex geological dynamics of the island.

In fact, during the different phases of colonization recorded on the island, the Ischia volcanoes were very active and produced explosive and effusive eruptions, accompanied by a strong geological dynamics that included earthquakes, landslides (even gigantic ones), rapid ground uplift and strong hydrothermal activity.

In the room, the samples on display "tell” the evolution of the island and its dynamics in four windows and a chest of drawers, where there is an exposition of the products of the various eruptions, from the oldest to the most recent, sedimentary rocks and the collection of macro and microfossils found in marine sediments, displaced at variable altitudes by the rapid volcano-tectonic deformations that characterize the island.

A series of panels and monitors accompany the visitor along a path that, starting from the geological evolution of the island, passes through the relationship between humans and the volcano, the main volcanic phenomena and the reconstruction of an archaeological excavation of exceptional value, where it is possible to see the strong interaction between primary and secondary volcanic phenomena and a human settlement of the first Greek colony in the west: Pithecusae.

The exhibition was designed with the purpose of educating the visitors and the local population about the natural history of the island and its volcanoes, and their impact on the human life through time.
\end{abstract}

Keywords: Archaeology; Volcanology; Geological Museum; Dissemination; Ischia island. 


\section{Sandro de Vita et al.}

\section{Introduction}

The diffusion of knowledge about natural hazards is by far one of the most powerful tools of risk mitigation for the populations of the exposed areas. In fact, sharing rigorous, effective and easy to understand information is the first step towards the awareness and a more sustainable management of the territory, which eventually will greatly enhance the resilience of the societies exposed to various kinds of natural threats. In order to obtain satisfactory results in terms of civil protection, the culture of risk must be instilled in such a way as to permeate the social fabric, starting with school-age citizens and across all social classes [de Vita and Marotta, 2007]. To do this, the school is undoubtedly the main and most effective tool for reaching the youngest segments of the population, so as to mould consciences and address their behaviour towards a correct humans/environment relationship. Furthermore, the school, as an institutional educational subject, has the fundamental role of educating the younger generations, transmitting them, at the same time, a feeling of trust in scientific research and, more generally, in the value of culture. Many other communication tools exist nowadays, to pursue the same objectives, even outside the world of school, from the traditional mass-media to the web and up to the most current social-media (Lee, 2010; Selwyn and Stirling, 2016). In the past decades, however, also museums played an important role in this perspective. Mainly science museums and the so-called Science Centers have evolved, proposing themselves as didactic tools for the dissemination of knowledge, rather than mere exhibition places for an élite of specialists or a cultured public of enthusiasts. The exhibition itineraries have been reorganized according to new educational criteria and have been aimed at teaching and outreach, to meet the needs of an increasingly large, varied and motivated public. An exhaustive, rigorous and up to date information has the chance of reaching a wide range of people if it is transmitted in a snappy and fascinating way and, with the new millennium, the development of the most advanced multimedia and interactive technologies has significantly enhanced the transformation process of museum exhibitions, in the direction of a more accessible, captivating and engaging communication.

In this work we will illustrate the setting up of the geological section of the Archaeological Museum of Villa Arbusto in Lacco Ameno (Ischia, Naples - Italy; Figure 1), which is dedicated to the memory of the archaeologist Giorgio Buchner and is intended as an example of integration between conventional and innovative exhibition strategies. In compliance with the classic exhibition mode of the Archaeological Museum, the new geological section implements the wonderful Buchner's collections of rocks and fossils, with dioramas, computer graphic reconstructions and HD documentaries, whit the aim of educating the visitors and the local population about the natural history of the island and its volcanoes, and their impact on the human life through time.

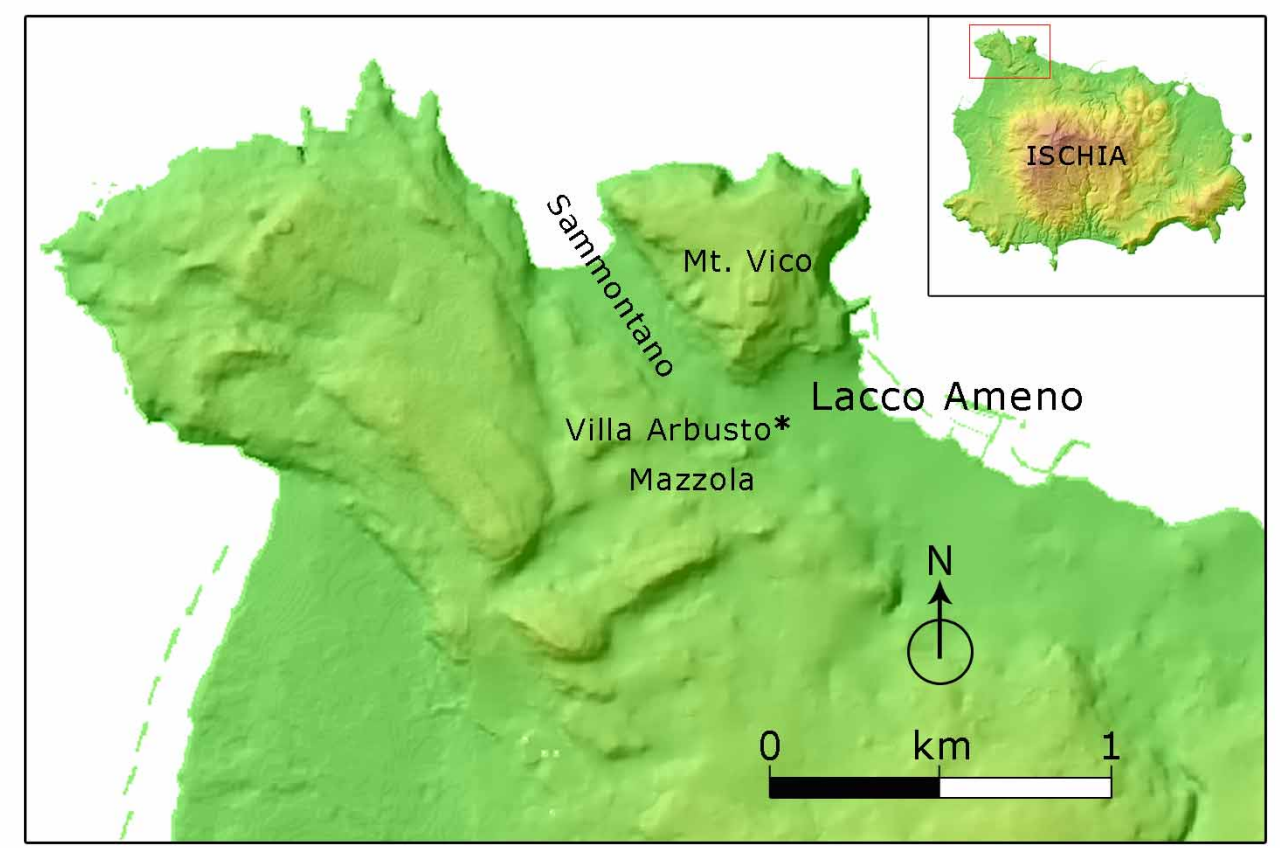

Figure 1. Location of the Villa Arbusto Archaeological Museum. *Coordinates UTM WGS84: 33T 405782 E, 4511997 N. 
As it was conceived, the geological section of the museum can be considered as a gateway to the visit and knowledge of the island and its spectacular natural heritage, which makes the island itself an open book on almost all the volcanic and related phenomena present in nature.

\section{The role of modern museums in the dissemination of knowledge}

The idea of collecting uncommon objects, artifacts of particular beauty or natural wonders, and exhibiting to show them to a more or less wide audience, is at the origin of the very concept of "museum" and, likely, has its roots in the very origins of humankind. Although the habit of creating collections of objects is not exclusive to the genus Homo, as it is reflected in numerous species of birds, fish and mammals, it is with the humans of the Paleolithic that this attitude develops to become an archetype of the museum and evolves, later, as a testimony of cultural prestige or wealth to be flaunted [Gioia, 2010]. This has become particularly true since the conquest of Magna Graecia by the Romans, who began to adorn public places and private houses with works looted and brought back home as spoils of war. During the Middle Ages, collecting remained linked to this scheme or to the work of the Church, which collected sacred relics and ex-voto, and to the trade that developed during the Crusades with the Near East. It was with Humanism that the first rationally organized private collections took place, for purely cultural purposes, and there were the first phenomena of conservation of artistic and historical documents in public spaces [Gioia, 2010]. In this period there is the birth of the so-called studioli (or studium musarum), Italian anticipation of the late fifteenth century Germanic Wunderkammer, but it is due to Pope Sixtus IV, in 1471, with the donation to the Roman people of a collection of ancient bronzes, the foundation of the first public collection, and therefore the oldest art exhibition in the world, known as the Capitoline Museums [AA.VV., 2005]. Later, the concept of the museum has been continuously evolving, until the Enlightenment, when the times have become ripe for the opening to the public of museums with a dissemination function, organized according to the dictates of the first treatise on museography, written by Caspar Friedrich Neickel in 1727, in which the formative function of museums towards society is clearly asserted [Guerriero, 2013]. The past three centuries have seen museums open up all over the world, diversifying themselves according to the types of cultural heritages exhibited, from ethnographic and peasant culture museums, to museums of space technologies, and no longer just museums of art and natural sciences. Once the process of opening to the public has begun, it has never stopped and, increasingly, museums have become accessible to all social classes and age groups, and have confirmed their vocation as places for training, sharing and teaching, as well as for conservation and preservation of cultural heritage. The growing need for coordination at an international level, between museums, in terms of sharing intentions and methodologies, led to the creation of the International Council of Museums (ICOM) in 1946. ICOM is a non-governmental international organisation, which establishes professional and ethical standards for museum activities, and is "committed to the research, conservation, continuation and communication to society of the world's natural and cultural heritage, present and future, tangible and intangible" [ICOM website, https://icom.museum/en/]. According to the most update ICOM definition, a museum is a nonprofit, permanent institution in the service of society and its development, open to the public, which acquires, conserves, researches, communicates and exhibits the tangible and intangible heritage of humanity and its environment for the purposes of education, study and enjoyment [ICOM, 2017]. Following this definition, mainly natural history museums and, more generally, science museums, have evolved over time, basing their exhibitions on educational-oriented criteria, according to the most modern concepts of teaching through interactivity and of learning by doing. With the advent of the internet, museums have moved towards the realization of the concept of a museum outside the walls, prefigured by Malraux [1967], intended as a museum that makes its information and knowledge available both to on-site and remote visitors [Arvanitis, 2010]. As new communication technologies became available, these were gradually introduced in museums, starting with audio guides and the so-called Personal Digital Assistants [Micha and Economou, 2005], up to mobile phones, which definitively allowed museums to enable remote access to their exhibitions, also to satisfy the need for social inclusion, improving access, outreach and dissemination of knowledge [Arvanitis, 2010]. Furthermore, thanks to the use of QR codes and, in perspective, of the most innovative DVR codes, museums are now able to expand their contents and increase their communication power, satisfying the public's request for further information on a variety of topics.

However, although towards the end of the past century museography made a qualitative leap with the adoption of techniques aimed at communicating with the public and satisfying its needs, especially in scientific exhibitions, 


\section{Sandro de Vita et al.}

and despite the advances in technology and empowering of communication tools, many museums still retain a nineteenth-century organization, with paths without logic, with rooms full of showcases, in turn full of objects, often identified only by scanty tags.

The definition of a museum itself, almost unchanged in the last 50 years, is now under discussion, in light of the need to have also a social and inclusive role in breaking down cultural barriers, because they work for diverse community and would contribute to human dignity and social justice, global equality and planetary well-being [Sandahl, 2019; Marshall, 2020].

The setting up of the geological section of the Archaeological Museum of Villa Arbusto was thought in line with these latest trends, both in terms of technologies and philosophy of communication. In particular, it was intended to give greater relevance to the educational connotation of the exhibition, in order to contribute to the mitigation of risk by increasing awareness, which in turn derives from a more accurate knowledge of the territory and its natural history and hazards.

\section{The Villa Arbusto archaeological museum of Ischia}

The history of the Greek colonization of the western Mediterranean has been rewritten, and deeply revolutionized, by the researches and the excavations carried out by the eminent archaeologist Giorgio Buchner at Ischia. Starting from what Titus Livius (VIII 22) and Strabo (V 247 C) reported, referring to the Timaeus of Tauromenion's writings, he was persuaded that the Greek colonization of the West had originated from the foundation of Pithekoussai (Ischia) in the $8^{\text {th }}$ century BC by the Euboic settlers of Chalcis, who only later moved to the continent to found the city of Cuma, on the Phlegraean coast [Buchner and Gialanella, 1994]. Aimed at finding the evidence of this and based on widespread findings of geometric pottery of the $8^{\text {th }}$ century BC, Buchner began an extensive campaign of excavations in the northwestern part of the island in 1952 (Figure 2). At the end of the works, in 1983, Buchner brought to light the necropolis in the valley of Sammontano, with burials dating from the $8^{\text {th }}$ century BC to the $3^{\text {rd }}$ century AD, and the so-called metallurgical district in Mazzola, which, with the recovery of the material of the "Gosetti" dumping, on the acropolis of Mt. Vico, made it possible to demonstrate that around $750 \mathrm{BC}$ the colony of Pithekoussai had already reached such an extent that it could be certainly considered the first stable Greek settlement in Italy, datable to second quarter of the $8^{\text {th }}$ century BC [Gialanella, 2012]. On the basis of Buchner's findings it was possible to state that this Greek settlement played a role of primary importance for the birth of the Magna Graecia civilization. In fact, Pithekoussai was a manufacturing center of finished metallurgical and terracotta products, which were marketed especially towards the emerging populations of central Italy, for which the foundation of Pithekoussai has meant, among other things, the possibility of assimilating the knowledge of the alphabetic writing [Buchner and Ridgway, 1993; Buchner and Gialanella, 1994; Gialanella, 2012].

The huge amount of archaeological material of inestimable historical value, extracted during the excavations, was described, together with the contexts and the excavation data, in the valuable publication Pithekoussai I [Buchner and Ridgway, 1993]. This publication provided a subtle and rigorous interpretation of the social reality of the Greek colony and its cultural relationship with the variegated indigenous community of the Iron Age. A complex trade network with the main Mediterranean settlements emerged as well, testified by objects imported from the Near East and Carthage, Greece and Spain, southern Etruria, up to Apulia, Ionian Calabria and Sardinia [Buchner and Ridgway, 1993]. Buchner's discoveries in Pithecoussai, in the archaeological, historical and ethnographic field, were so relevant that it was immediately evident the need to create a museum to show the results of the excavations to the public. Nevertheless the archaeological museum of Villa Arbusto was officially inaugurated only in 1999.

The long process of museum realization was completed when, having overcome all the bureaucratic obstacles, the administration of the city of Lacco Ameno managed to purchase the complex of Villa Arbusto (Figure 3). This is located in a panoramic position on a hill close to the Sammontano valley and in front of Mt. Vico, which were the sites of the necropolis excavated by Buchner and the acropolis of the ancient Pithekoussai, respectively. The villa is also located few steps away from the $8^{\text {th }}$ century BC metallurgical district, in the locality of Mazzola [Figure 1; Buchner and Gialanella, 1994].

Villa Arbusto originated as a rural complex, transformed in a luxurious country residence by the Duke of Atri in 1785. It includes the main villa, surrounded by a large garden, in which a minor building for guests, a chapel, a room for the therapeutic exploitation of hot fumaroles, a cistern for collecting rainwater and a lovely fountain are present. 


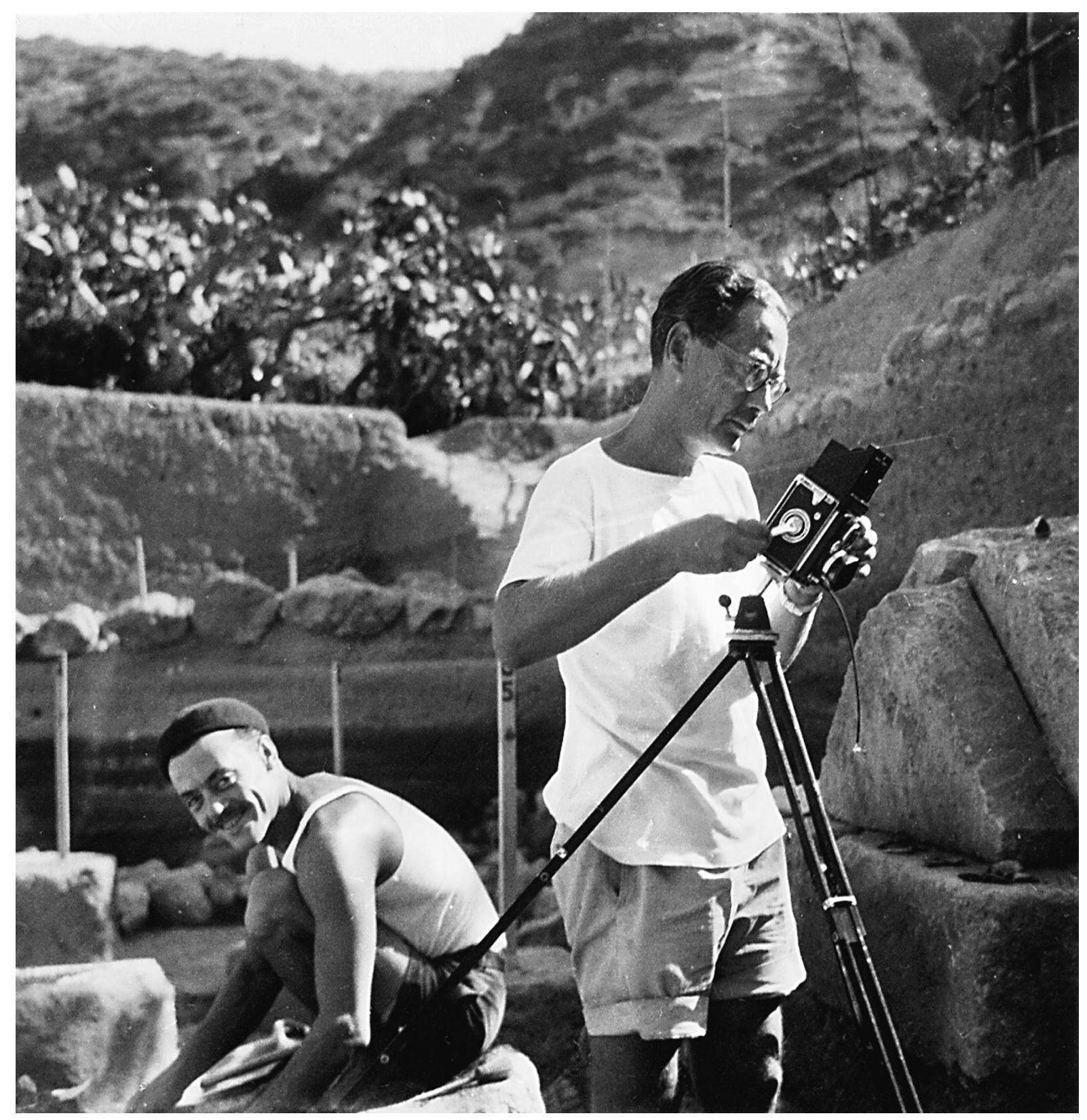

Figure 2. Giorgio Buchner during the excavation of the necropolis of Pithekoussai.

The museum is housed on the first floor of the main building and develops through eight rooms, in which the archaeological findings are exhibited according to the Buchner's vision, who said: "Nowadays the purpose of the scientific archaeological excavation is no longer the recovering of single objects of nice aesthetic appearance and antiquarian curiosity, but that of knowing, through the material and other information collected in the excavation, the history of the populations of the past, intended not so much a political history of rulers and wars as knowledge of ways of life, of the social structure of human agglomerates, of the commercial exchanges indicated by objects imported from other regions or exported, and of the mutual cultural exchanges between different civilizations" [website of the Lacco Ameno Municipality; https://www.comunelaccoameno.it/vivere-a-lacco-ameno/archeologia].

In order to fulfil this mission, the museum exhibits findings illustrating the history of human frequentation of Ischia from the Neolithic to the Roman age. Each room is set up in order to exhibit the findings related to a different era, illustrating the culture and traditions of the people who produced them. More than one thousand findings are exposed in the museum, most of which, mainly pottery, bear witness to the ancient Pithekoussai. Among these, the most important object is by far the so-called Nestor's cup, a Rhodian kotyle discovered in a cremation burial, which 


\section{Sandro de Vita et al.}

offers a secure archaeological date in the period of Late Geometric II, around 725-720 BC [Ridgway, 1992; Buchner and Ridgway, 1993; Murray, 1994]. This cup is engraved with an epigram in three lines, written in the Euboic alphabet, which alludes to the famous cup of Nestor described in the Homer's Iliad, and it is one of the oldest examples of alphabetic writing, ever discovered in the western Mediterranean [Buchner and Ridgway, 1993].

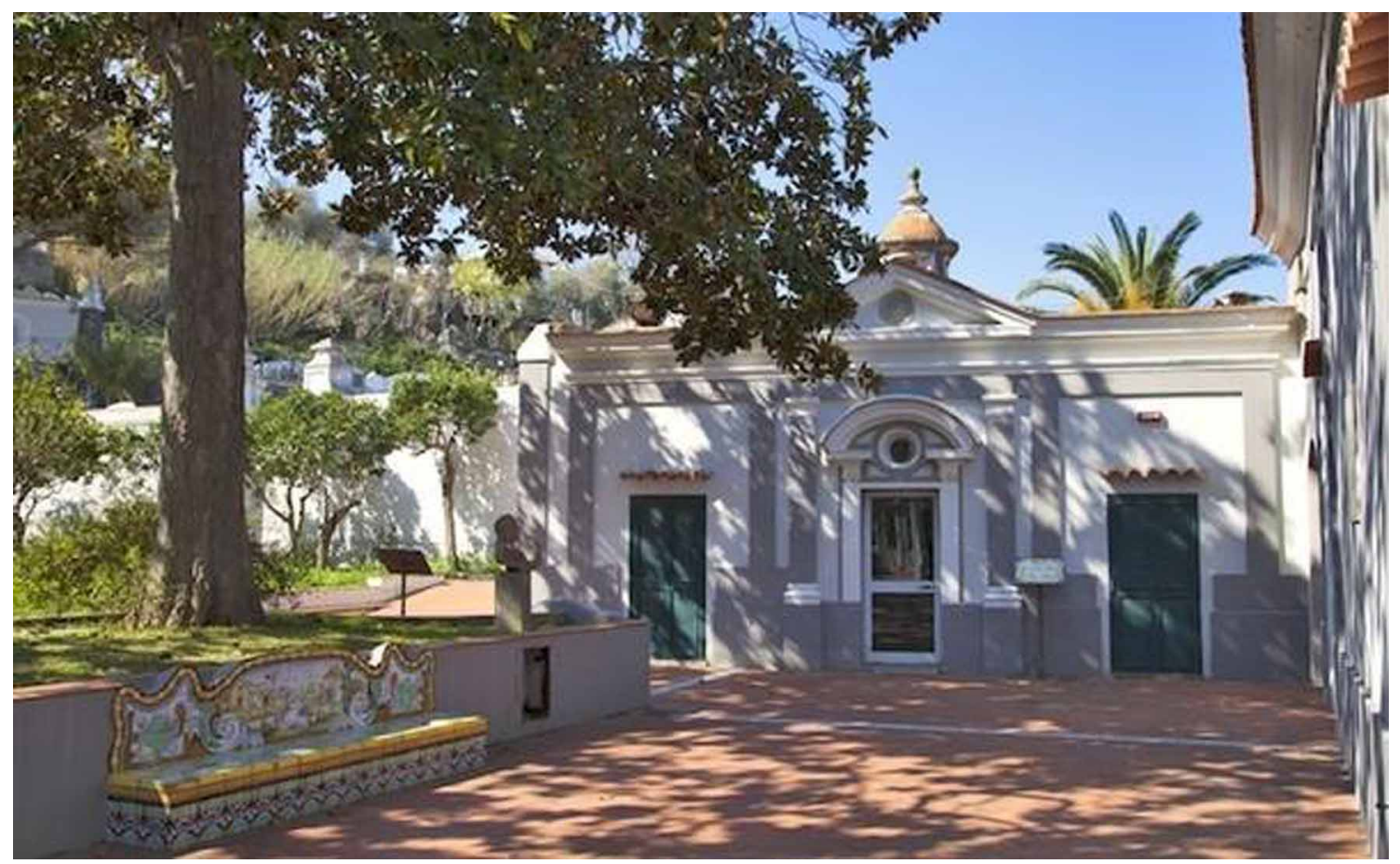

Figure 3. Villa Arbusto at Lacco Ameno (Ischia), the site of the archaeological Museum of Pithekoussai.

\section{The "Giorgio Buchner" geological section}

Buchner's archaeological researches were conducted at Ischia according to his cultural formation, which, although maintaining a rigorous humanistic and historical basis, presupposed a close integration with geological and natural sciences [Pacciarelli, 2011; de Vita et al., 2011]. In fact, following the teaching of his father Paul (a well-known naturalist) and attending the famous volcanologist Alfred Rittmann, Buchner carried out numerous geological surveys in the Pontine and Phlegraean archipelagos, as well as in Capri and the Aeolian Islands. In particular, combined archaeological/geological surveys were carried out by the young Buchner at Ischia, where these two disciplines are strictly linked to each other. In this island the history of human settlements was strongly conditioned by the occurrence of often devastating volcanic and related phenomena. During the different phases of colonization recorded on the island, indeed, the Ischia volcanoes were very active and produced explosive and effusive eruptions, accompanied by a strong geological dynamics that included earthquakes, landslides (even gigantic ones), rapid ground uplift and strong hydrothermal activity [Buchner, 1986; Gialanella, 1994; de Vita et al., 2006; 2010; 2013; Della Seta et al., 2012; 2021]. For a long time, Buchner deemed that "his" museum would not be complete until it was equipped with a geological section, illustrating the complex interactions between repeated episodes of colonization and abandonment of the island of Ischia and catastrophic natural phenomena. A first attempt in this direction had already been made in 1948, when a geological and archaeological museum of Ischia was opened for a short time [Buchner and Rittmann, 1948]. But it was only in June 2019 that a room in the Archaeological Museum of Villa Arbusto was set up to house the collection of rocks and fossils collected by the renowned archaeologist during his excavations on the Island of Ischia (Figure 4). The collection is witness to a long multidisciplinary research activity that saw archaeological studies at the center of volcanological, pedological and palaeoenvironmental researches, aimed at reconstructing the archaeological contexts in the framework of the complex geological dynamics of the island. The samples on display "tell" the evolution 
of the island and its dynamics in four windows and a chest of drawers, where an exposition of the products of the various eruptions is present, from the oldest to the most recent, as well as sedimentary rocks and the collection of fossils and microfossils found in marine sediments, now displaced at variable altitudes, testifying the rapid volcano-tectonic deformations that characterize the island. Each showcase represents a step in the geological evolution of the island, and contains a digital photoframe with a slideshow that illustrates the lithological characteristics of the exposed rocks, their mechanism of formation, the sampling outcrop and the stratigraphic unit they belong to (Figures $5 \mathrm{a}$ and $5 \mathrm{~b}$ ).

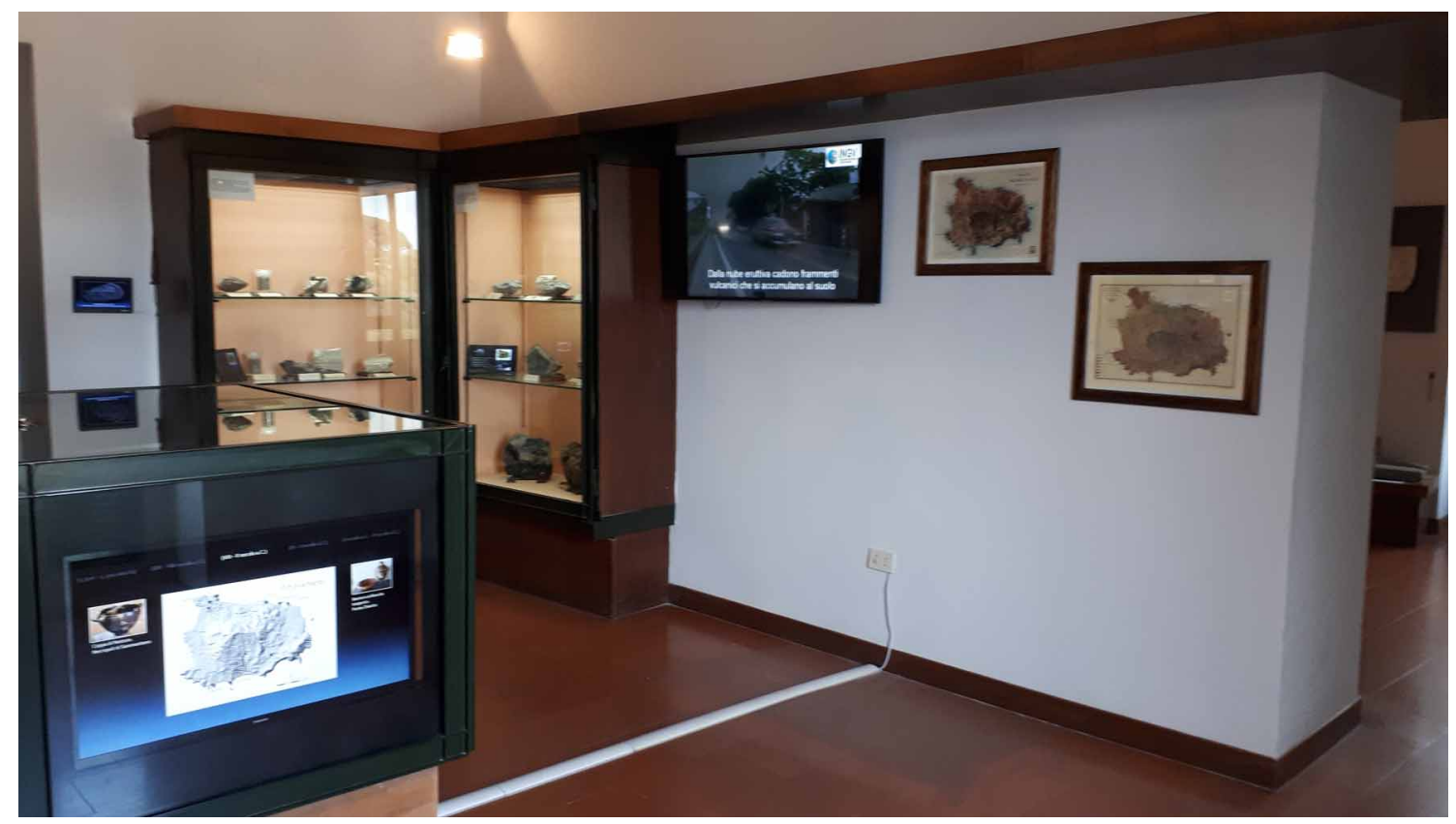

Figure 4. The geological section of the museum, with old geological maps, rock samples and multimedial exhibits illustrating the geological evolution of the island.

In the chest of drawers, with the Buchner's bust, are exposed the fossils found in marine sediments, (Figure 6a). A digital photoframe, on the wall next to the chest of drawers, shows the microfossils found in the same sediments, and illustrate their significance in terms of palaeoenvironmental reconstruction (Figure 6b).

A series of panels and monitors accompany the visitor along a path that, starting from the geological evolution of the island, passes through the relationship between humans and the volcano, the main volcanic phenomena and the reconstruction of an archaeological excavation of exceptional value, where it is possible to see the strong interaction between primary and secondary volcanic phenomena and a human settlement of the first Greek colony in the west.

In particular, the geological history of Ischia is illustrated through a video with short and easy-to-understand texts, 3D reconstructions, photos and simple diagrams, to traces the main evolutionary phases of the island and the volcanic and morphostructural phenomena that led to its present setting. The exhibition is enriched by the reproduction of some historical geological maps, published starting from 1847, which illustrate the evolution of the scientific thought, over time, in the interpretation of the geology of the island. The impact of volcanic and related phenomena on human settlements, since Neolithic, is shown in a multimedia showcase (Figure 7), in which a diorama reproduces the archaeological site of Punta Chiarito, destroyed by an explosive eruption and a debris avalanche. Videos running on two monitors allow visitors to view the location of human settlements on the island, in the different eras, and the areal distribution of the eruptive deposits that affected them. The exhibition itinerary ends with a video in which, using films related to volcanic eruptions occurred in recent times in different parts of the world, are reproduced the eruptive phenomena occurred at Ischia in the past, which were responsible for the formation of the volcanic rocks presently exposed on the island.

All the information available through the exhibition itinerary represents a very useful guide for visitors who want to plan a tour to discover the natural wonders of the island and the phenomena that produced them. 


\section{Sandro de Vita et al.}

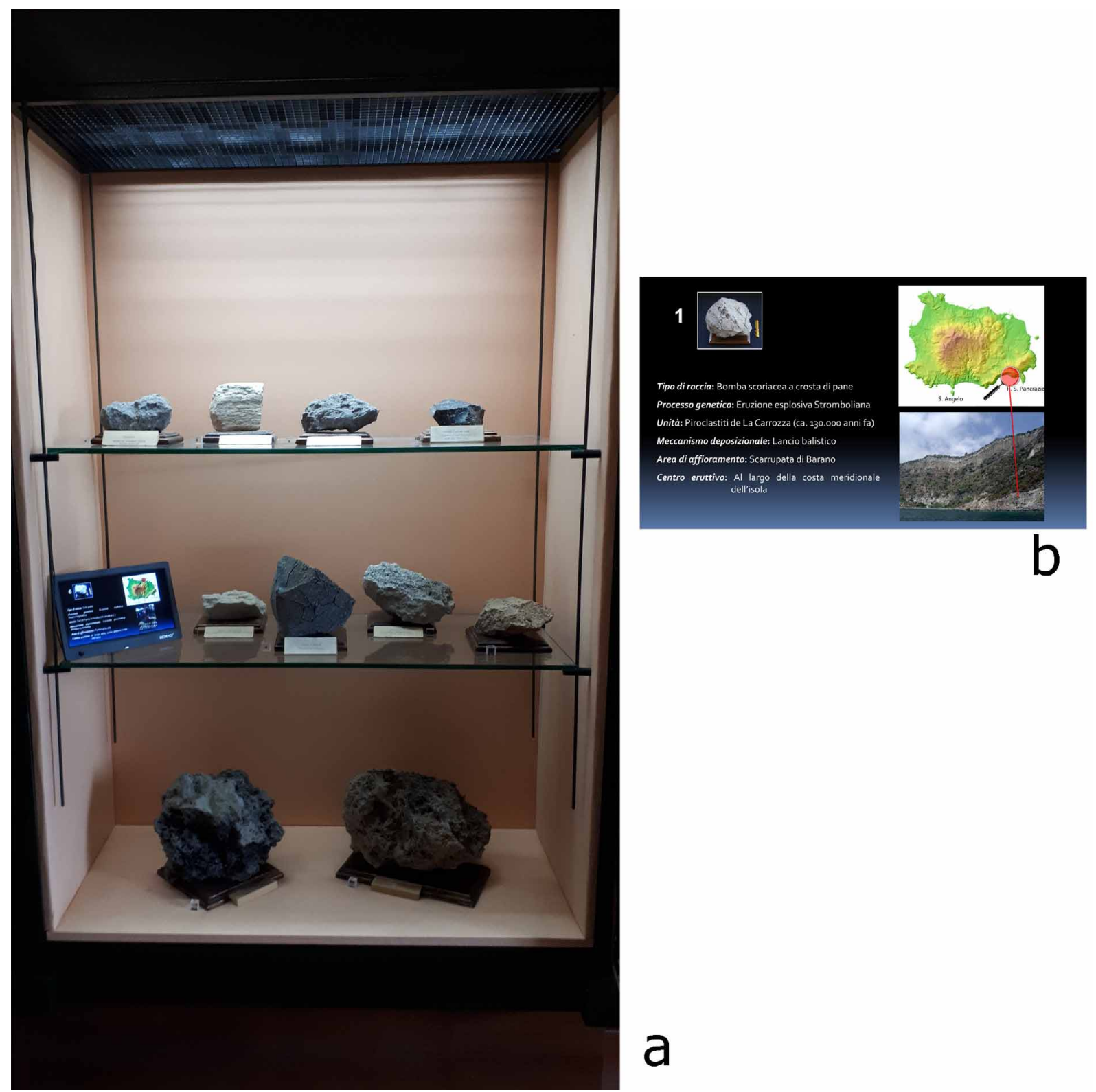

Figure 5. a) One of the showcases illustrating the geological evolution of Ischia, through the exposition of representative rock samples, with the original Buchner's typewritten tags; b) Screenshot of the digital photoframes that describe the characteristics of the exposed samples.

\section{Conclusions}

The Archaeological Museum of Villa Arbusto shows the history of human settlements at Ischia from Neolithic to the Roman era, through the findings brought to light by Giorgio Buchner, the archaeologist who, with his discoveries, proved that the island was the site of the first Greek colony in the western Mediterranean: Pithekoussai. This, founded in the second quarter of the $8^{\text {th }}$ century BC, played a fundamental role in the birth of Magna Graecia and in the spread of Greek culture and alphabetic writing in the Iron Age of Italy [Ridgway, 1992; Buchner and Ridgway, 1993]. The geological nature of the island, however, as in all areas of active volcanism, caused the alternation of episodes of human colonization and natural disasters, which have repeatedly destroyed settlements and displaced the population. Volcanological and archaeological researches carried out on the island have shown that volcanic activity, ground 


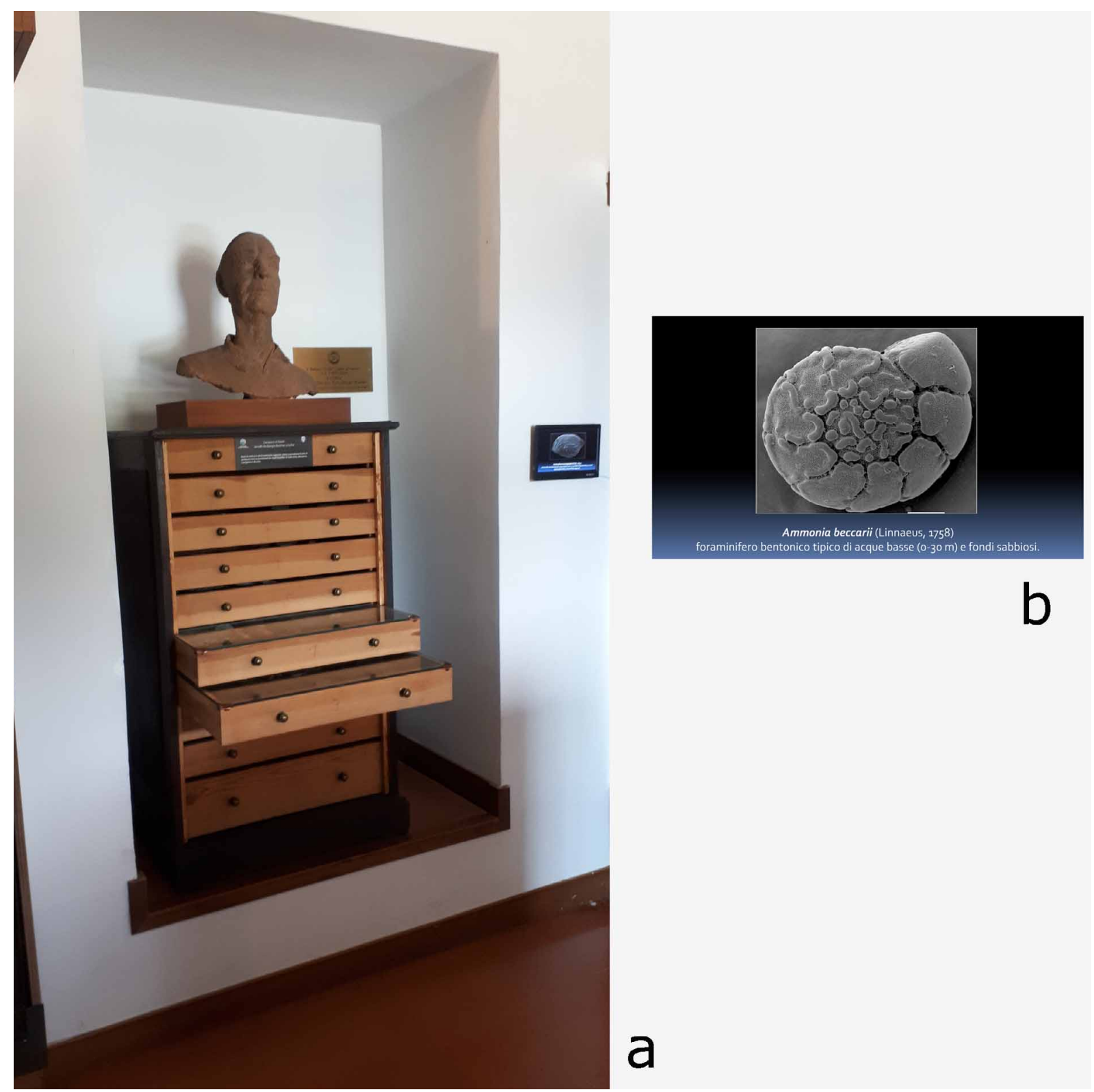

Figure 6. a) The Buchner's bust and his chest of drawers with the marine fossils collected by the archaeologist; b) Screenshot of the digital photoframe that shows the microfossils found in marine sediments. The information on the height of displacement, age and environment of sedimentation allow to determine amount and rate of uplift.

deformations and slope instability have been particularly intense just when the impulse for civilization was stronger [Buchner, 1986; Gialanella, 1994; de Vita et al., 2006; 2010; 2013; Della Seta et al., 2012; 2021].

The geological section of the museum, strongly desired by Buchner himself, was recently created, just to illustrate the complex interactions between repeated episodes of colonization and abandonment of the island of Ischia and catastrophic natural phenomena. The exhibition was designed with the purpose of educating the visitors and the local population about the natural history of the island and its volcanoes, and their impact on the human life through time. The section has been set up by the Naples section of INGV (Osservatorio Vesuviano) in collaboration with the Archaeological Superintence and the DISTAR of the University of Naples Federico II. This activity is included in the framework of information and scientific dissemination programs, carried out by INGV and aimed at improving risk mitigation by increasing awareness and developing a culture of coexistence with natural hazards. 


\section{Sandro de Vita et al.}

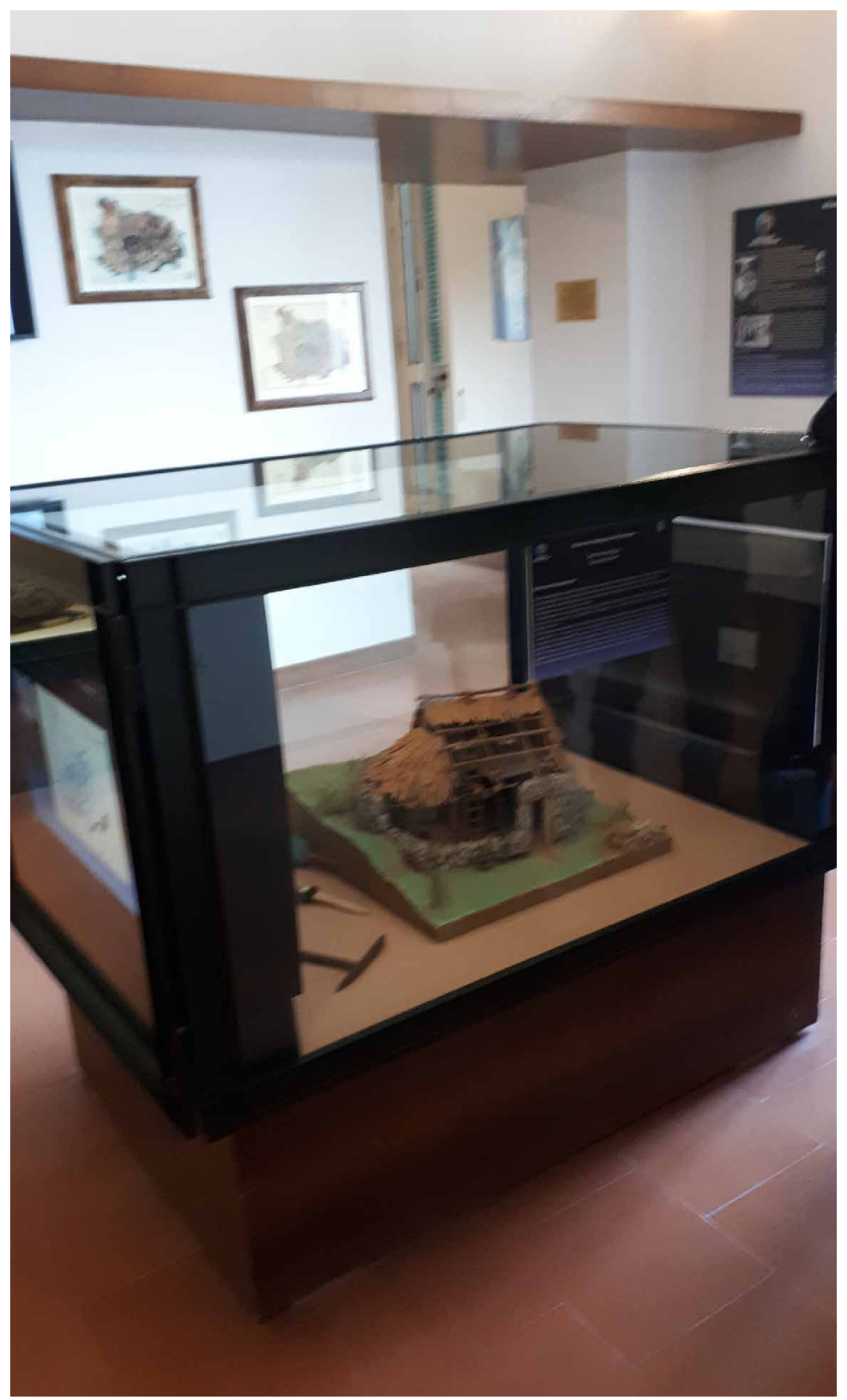

Figure 7. The multimedia showcase with two monitors illustrating the relations between humans and volcanic activity at Ischia, and the reconstruction of a Greek settlement of the $8^{\text {th }}-6^{\text {th }}$ century BC.

Acknowledgments. This work has been realized with the financial support of Fondazione con il Sud (Brains2 Islands project) and the Italian Department of Civil Defence (DPC-INGV 2019-2021 convention, Annex B2, Task 15). The Naples Archaeological Superintendent, Dr. Teresa Cinquantaquattro, and the personnel of the Archaeological Museum of Villa Arbusto are warmly thanked for the support provided during the setting up of the Buchner's geological section. Our gratitude also goes to two anonymous reviewers, whose comments greatly improved the quality of this paper.

\section{References}

AA.VV. (2005). Musei Capitolini. Guida, Roma 2005.

Arvanitis, K. (2010). Museums outside walls: mobile phones and the museum in the everyday, in Museums in a digital age, R. Parry (Editor), Routledge, London and New York, 170-176. 
Buchner, G. (1986). Eruzioni vulcaniche e fenomeni vulcanotettonici di età preistorica nell'isola d'Ischia, in Tremblements de terre, éruptions volcaniques et vie des hommes dans la Campanie antique, C. Albore Livadie (Editor), Bibliothèque de l'Institut Francais de Naples, Deuxième série, VII, 145-172. Publications du Centre Jean Bérard. Naples.

Buchner, G. and C. Gialanella (1994). Museo Archeologico di Pithecusae - Isola d'Ischia. Itinerari n. 22. Ministero per i Beni Culturali e Ambientali. Istituto Poligrafico e Zecca dello Stato - Libreria dello Stato.

Buchner, G. and D. Ridgway (1993). Pithekoussai I, La necropoli. Monumenti antichi dei Lincei, serie monografica IV. Roma.

Buchner, G. and A. Rittmann (1948). Origine e passato dell'isola d'Ischia. Macchiaroli, G. (Editor), Napoli, 80.

Della Seta, M., E. Marotta, G. Orsi, S. de Vita, F. Sansivero and P. Fredi (2012). Slope instability induced by volcanotectonics as an additional source of hazard in active volcanic areas: the case of Ischia island (Italy), Bull. Volcanol., 74, 1, 79-106. Doi:10.1007/s00445-011-0501-0.

Della Seta, M., C. Esposito, M. Fiorucci, G.M. Marmoni, S. Martino, G. Sottili, P. Belviso, A. Carandente, S. de Vita, E. Marotta and R. Peluso (2020). Thermal monitoring to infer possible interactions between shallow hydrothermal system and slope-scale gravitational deformation of Mt. Epomeo (Ischia, Italy), Geol. Soc. London, Sp. Pub. (in press).

Della Seta M., Esposito C., Fiorucci M., Marmoni G.M., Martino S., Sottili G., Belviso P., Carandente A., de Vita S., Marotta E., Peluso R., 2021. Thermal monitoring to infer possible interactions between shallow hydrothermal system and slope-scale gravitational deformation of Mt. Epomeo (Ischia Island, Italy). In: Marotta, E., D’Auria, L., Zaniboni, F. and Nave, R. (eds) Volcanic Island: from Hazard Assessment to Risk Mitigation. Geological Society, London, Special Publications, 519, https://doi.org/10.1144/SP519-2020-131.

de Vita, S., M.A. Di Vito, E. Marotta and F. Sansivero (2011). Giorgio Buchner precursore del rapporto tra archeologia e vulcanologia: il ruolo delle determinazioni crono-archeologiche nella ricostruzione della storia vulcanica e deformativa recente dell'isola d'Ischia, in Dopo Giorgio Buchner. Studi e ricerche su Pithekoussai, Gialanella, C. and P. Guzzo (Editors), Naus Editoria, 75-95.

de Vita, S., M.A. Di Vito, C. Gialanella and F. Sansivero (2013). The impact of the Ischia Porto Tephra eruption (Italy) on the Greek colony of Pithekoussai, Quat. Int., 303, 142-152.

de Vita, S. and E. Marotta (2007). Terra di vulcani. Ed. L'Arca e l'Arco, Nola (NA), 144.

de Vita, S., F. Sansivero, G. Orsi and E. Marotta (2006). Cyclical slope instability and volcanism related to volcanotectonism in resurgent calderas: the Ischia island (italy) case study, Eng. Geol., 86, 148-165.

de Vita, S., F. Sansivero, G. Orsi, E. Marotta and M. Piochi (2010). Volcanological and structural evolution of the Ischia resurgent caldera (Italy) over the past $10 \mathrm{ka}$, Geol. Soc. of Am. Special Paper, 464, 193-239.

Gialanella, C. (1994). Pithecusa: gli insediamenti di Punta Chiarito. Relazione preliminare. Aтоıкı $\alpha$, scritti in onore di Giorgio Buchner. Annali di archeologia e storia antica, nuova serie n. 1, 169-204. Istituto Universitario Orientale di Napoli.

Gialanella, C. (2012). Il Museo Archeologico di Pithecusae. Ministero peri i Beni e le Attività Culturali Soprintendenza Speciale per i Beni Archeologici di Napoli e Pompei. Ed. Nuvola Grafica.

Gioia, P. (2010). Lezioni del corso di Museologia e Archeologia. A.A. 2010-2011, Università di Roma "La Sapienza". http://cisadu2.let.uniroma1.it/archeo/orari/LezioniGioia1011.htm.

Guerriero, G. (2013). Il Museo dell’Osservatorio Vesuviano: una proposta di riallestimento. Master degree Thesis. Università degli Studi di Napoli Federico II, 79.

ICOM (2017). International Council of Museum Statutes, as amended and adopted by the Extraordinary General Assembly on 9th June 2017 (Paris, France). ICOM website (https://icom.museum/en/resources/standardsguidelines/museum-definition/).

Lee, A. Y. (2010). Media education: Definitions, approaches and development around the globe, New horizons in education, 58, 3, 1-13.

Malraux, A. (1967). Museum without Walls, trans. Stuart Gilbert and Francis Price, London: Martin Secker \& Warburg.

Marshall, A. (2020). A tougher-than-expected question: what is a Museum? The New York Times of August 12, 2020, Section C, Page 6 of the New York edition.

Micha, K. and D. Economou (2005). Using Personal Digital Assistants (PDAs) to Enhance the Museum Visit Experience, in Advances in Informatics. PCI 2005. Lecture Notes in Computer Science, vol 3746, Bozanis P. and 


\section{Sandro de Vita et al.}

E.N. Houstis (Editors), Springer, Berlin, Heidelberg. https://doi.org/10.1007/11573036_18

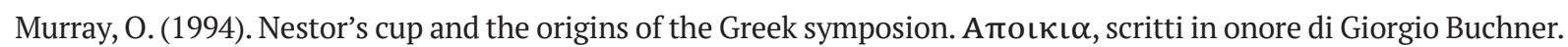
Annali di archeologia e storia antica, nuova serie n. 1, 47-54. Istituto Universitario Orientale di Napoli.

Neickel, C. F. (1727). Museographia oder Anleitung zum rechten Begriff un nützlicher Anlegung der Museorum, oder Raritären-Kammern [Museography or instructions for creating correct and useful displays for museums or cabinets of curiosities], trans. (Italian) E. Giovannini, ed. M. Pigozzi, E. Giuliani and A. Huber. Bologna: CLUEB, 2005.

Pacciarelli, M. (2011). Giorgio Buchner e l'archeologia preistorica delle isole tirreniche. In: Gialanella, C. and Guzzo, P. (Eds.), Dopo Giorgio Buchner. Studi e ricerche su Pithekoussai. Naus Editoria, 43-56.

Ridgway, D. (1992). The first western Greeks. Cambridge University Press Archive, 180.

Selwyn, N. and E. Stirling (2016). Social media and education... now the dust has settled, Learning, media and technology, 41, 1, 1-5.

Sandahl, J. (2019). The Museum Definition as the Backbone of ICOM, Museum International, 71 (1-2), p.i. https://doi.org/10.1080/13500775.2019.1638019. 